\title{
Macroeconomic Regime Switches and Speculative Attacks
}

\section{Bartosz Maćkowiak*}

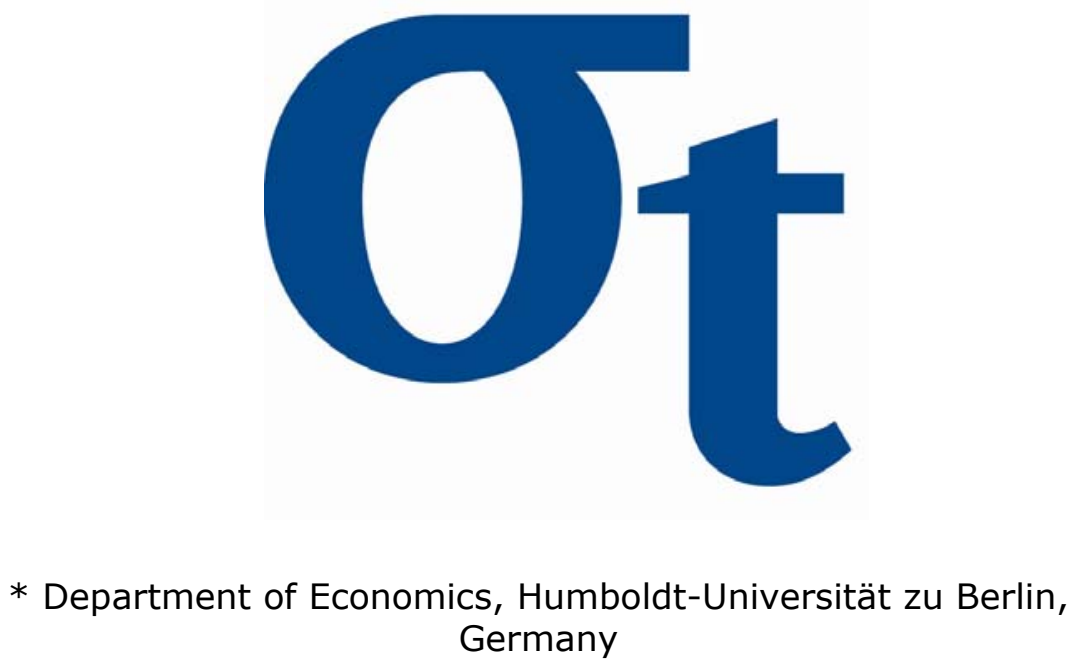

This research was supported by the Deutsche

Forschungsgemeinschaft through the SFB 649 "Economic Risk".

http://sfb649.wiwi.hu-berlin.de ISSN 1860-5664 


\title{
Macroeconomic regime switches and speculative attacks*
}

\author{
Bartosz Maćkowiak \\ Humboldt University Berlin
}

Revised March 2006

\begin{abstract}
This paper explains a currency crisis as an outcome of a switch in how monetary policy and fiscal policy are coordinated. The paper develops a model of an open economy in which monetary policy starts active, fiscal policy starts passive and, in a particular state of nature, monetary policy switches to passive and fiscal policy switches to active. The probability of the regime switch is endogenous and changes over time together with the state of the economy. The regime switch is preceded by a sharp increase in interest rates and causes a jump in the exchange rate. The model predicts that currency composition of public debt affects dynamics of macroeconomic variables. Furthermore, the model is consistent with evidence from recent currency crises, in particular small seigniorage revenues.
\end{abstract}

JEL: E52, E61, F33.

Keywords: Coordination of monetary policy and fiscal policy, policy regime switch, currency crisis, speculative attack, fiscal theory of the price level.

${ }^{*}$ I thank for comments Chris Sims, Bill Brainard, Michael Burda, John Cochrane, Giancarlo Corsetti, Monique Ebell, Gauti Eggertsson, Itay Goldstein, Pierre-Olivier Gourinchas, Hélène Rey, Albrecht Ritschl, Nikola Tarashev, Harald Uhlig, Michael Woodford, anonymous referees and numerous seminar participants. This research was supported by the Deutsche Forschungsgemeinschaft through the Collaborative Research Center 649 Economic Risk. Email: bartosz@wiwi.hu-berlin.de. 


\section{Introduction}

It is common to specify macroeconomic policy in terms of one of two polar regimes and study what each regime implies for dynamics of macroeconomic variables. In one regime monetary policy obeys the Taylor (1993) principle and the budget surplus rises strongly with real value of public debt. In the other regime the Taylor principle fails to hold and the budget surplus follows an exogenous stochastic process. Leeper (1991) calls the former regime the active monetary passive fiscal regime. He calls the latter regime the passive monetary active fiscal regime. The former regime is consistent with standard monetarist intuition and is a plausible description of how monetary policy and fiscal policy are coordinated in "normal times" in most economies. The latter regime gives rise to the "fiscal theory of the price level" ${ }^{1}$ and is a plausible description of how monetary policy and fiscal policy are coordinated at a time of a fiscal emergency. For example, Woodford (2001) interprets the policy coordination in the Unites States during and immediately after World War II in terms of the passive monetary active fiscal regime.

Almost all papers thus far study either one regime or the other. But if both regimes can occur in the real world, it is worthwhile to develop models in which both regimes $d o$ occur. This paper develops a model of an open economy in which policy starts out in the active monetary passive fiscal regime and, at a time of a fiscal emergency, policy switches to the passive monetary active fiscal regime. A fiscal emergency is a state of nature such that expected future primary budget surpluses reach an upper bound due to a political constraint. The model considers a particular form of active monetary policy - a fixed exchange rate policy. The reason for the focus on this particular form of active monetary policy is that the model aims to explain the dynamics of collapse of a fixed exchange rate policy. The regime switch in the model causes a jump in the exchange rate - a currency crisis. The dynamics prior to the regime switch involve a sharp increase in interest rates like what we see in the real world during a speculative attack against a fixed exchange rate. A speculative attack in the model is caused by private agents' expectations of an imminent switch in how monetary policy and fiscal policy are coordinated.

The "first generation" model developed by Krugman (1979) and Flood and Garber

\footnotetext{
${ }^{1}$ See Sims (1994) and Woodford (1995).
} 
(1984) is a standard explanation of why a currency crisis occurs. That model assumes a constant monetary policy that expands domestic credit at a given rate both before and after a currency crisis. In contrast, in the model in this paper a currency crisis arises as an outcome of a switch in how monetary policy and fiscal policy are coordinated. Furthermore, the first generation model predicts that, after a currency crisis of large size, we will see large seigniorage revenues. This prediction is difficult to reconcile with recent episodes. Table 1 lists stylized facts about the currency crises in Mexico (1994), Korea (1997) and Turkey (2001). Each episode was associated with a large currency crisis and a large fiscal imbalance, but in each episode seigniorage revenues were small relative to the fiscal imbalance. The model in this paper predicts that the magnitude of a currency crisis will be large precisely when expected seigniorage revenues are small. In addition, the model predicts that, if the fiscal imbalance net of expected seigniorage revenues is large, we will see large fiscal gains due to a decrease in the real value of public debt and transfer payments. As Table 1 shows, in each crisis the sum of fiscal gains due to a decrease in the real value of public debt and fiscal gains due to a decrease in the real value of transfer payments was much larger than seigniorage revenues.

Furthermore, the paper identifies a condition for uniqueness of equilibrium in the active monetary passive fiscal regime when there exists a possibility of a switch to the passive monetary active fiscal regime. There is a unique equilibrium when the government will undertake sufficient fiscal reform coincident with the regime switch. Otherwise there are multiple equilibria. In the former case a currency crisis can still occur and, when it does, it is a unique equilibrium phenomenon. In the latter case a currency crisis can be a selffulfilling event. In the real world the extent of fiscal reform varies from episode to episode. See Table 1. The model suggests how we can infer whether a given currency crisis was a self-fulfilling phenomenon.

The first generation model has motivated empirical tests of predictability of currency crises. In contrast, the model in this paper suggests that a speculative attack and a currency crisis will be sudden and difficult to predict, even when equilibrium is unique. The model explains why in the real world we do not typically see currency crises preceded by smoothly rising interest rates or by a prolonged period with high and stable interest rates. 
This paper makes contact with the recent literature on currency crises. Daniel (2001) and Corsetti and Maćkowiak (2004) model a currency crisis in the passive monetary active fiscal regime. Burnside, Eichenbaum and Rebelo (2001, 2005) provide a quantitative analysis of a number of recent episodes. Those papers suppose that a regime switch has already taken place and ask what happens next. Furthermore, those papers assume perfect foresight. In contrast, the economy modeled in this paper is stochastic and starts out before a regime switch has taken place. Modeling the evolution of private agents' expectations regarding a regime switch yields predictions concerning macroeconomic dynamics. The paper finds that macroeconomic variables evolve differently in economies identical except for currency composition of public debt. The reason is that currency composition of public debt affects private agents' expectations regarding the probability and the size of a currency crisis. In particular, the paper finds that a currency crisis is delayed when a large fraction of public debt is denominated in a foreign currency. This result suggests why borrowing in a foreign currency can be attractive to policymakers. Governments in some countries that recently experienced a currency crisis had borrowed heavily in foreign currencies. See Section 2.

This paper also makes contact with the recent literature on regime switches in macroeconomic policy. Davig, Leeper, and Chung (2005) and Davig and Leeper (2005) develop models in which macroeconomic policy regime evolves according to a Markov process. ${ }^{2}$ In their work the probability of a regime switch is exogenous and constant. In this paper the probability of a regime switch is endogenous and changes over time together with the state of the economy. Furthermore, Sims (1997) discusses an example in which policy starts out in the active monetary passive fiscal regime and switches to the passive monetary active fiscal regime. Sims notes the possibility of multiplicity of equilibria, but his multiplicity seems more "benign" than the one found here. Sims's model contains a differential equation for public debt with two steady states, an upper one being unstable. If public debt starts out above the unstable steady state, a regime switch occurs in finite time. In contrast, in this paper there can be multiple solutions for a given initial amount of public debt. Thus the same initial conditions can be consistent with either a speculative attack and a regime

\footnotetext{
${ }^{2}$ See also Andolfatto and Gomme (2003) who assume that monetary policy evolves according to a Markov process.
} 
switch or continuation of the status quo.

The possibility of multiple equilibria plays an important role in the "second generation" model of currency crises. See, for example, Obstfeld (1994). ${ }^{3}$ The second generation model postulates that the government must pay a fixed cost when the fixed exchange rate is abandoned, for example a political cost. The second generation model makes different predictions from the model in this paper. The second generation model suggests that borrowing in a foreign currency can enhance government's credibility. The model in this paper suggests that policymakers can see borrowing in a foreign currency as attractive because it affects the dynamics of the economy, even when policy is perfectly credible. Furthermore, in the second generation model a currency crisis undermines government's credibility and this makes subsequent borrowing harder. In fact, governments in some countries that recently experienced a currency crisis were soon able to borrow the same amount and at lower interest rates compared to before the currency crisis. See Section 2. The model in this paper can match this evidence. There is also a difference in terms of methodology. While Obstfeld (1994) and the subsequent literature consider stylized twoperiod models, this paper develops a fully dynamic stochastic equilibrium model.

Section 2 describes the sequence of events that the paper aims to model. Section 3 sets up a dynamic stochastic model of a small open economy. Section 4 discusses what one can learn analytically about the model. In Section 5 the model is solved numerically and simulated. Section 6 concludes. Appendix A provides details of the numerical solution procedure used in Section 5. Appendix B lists sources for the data used in Section 2 and in Section 5 .

\section{The sequence of events}

This section describes the sequence of events that the paper aims to model. The currency crisis in Brazil in January 1999 serves as an example. Panel A in Figure 1 shows the expansion of public debt in Brazil in the two years prior to the currency crisis. The expansion of public debt reflected a "huge imbalance between what Brazilians demand of government

\footnotetext{
${ }^{3}$ See also the model of public debt in Calvo (1988).
} 
and how much they are willing to pay for." ${ }^{4}$ Panel B shows that in the run-up to the currency crisis more and more public debt was indexed to inflation or to the exchange rate. ${ }^{5}$ Panel $\mathrm{C}$ shows that foreign reserves decreased somewhat but remained close to 100 percent of the monetary base throughout the episode. Two speculative attacks caused two sharp increases in the short-term nominal interest rate and afterwards a large jump in the exchange rate took place. The currency lost about 30 percent of its value with respect to the dollar. The short-term nominal interest rate fell and stabilized soon after the currency crisis. See Panels D and E. Seigniorage revenues decreased to below pre-crisis levels. See Panel F. The currency devaluation caused a large decrease in the real value of public debt, as is apparent from Panel A. Within days of the currency crisis the legislature approved a package of fiscal reforms, including a controversial decrease in pension benefits. The same package had been rejected four times when the fixed exchange rate was in place. ${ }^{6}$ Soon after the devaluation the government was able to borrow about as much as two years prior to the crisis. See Panel A.

This suggests the following sequence of events to model. The government adopts a fixed exchange rate policy, which is a form of active monetary policy. ${ }^{7}$ Passive fiscal policy is put in place with the aim of making the fixed exchange rate sustainable. Public debt fluctuates over time due to shocks to revenues and expenditures. If the exchange rate is to remain fixed, current adverse fiscal shocks must be matched by improvements in future budgets. However, citizens want a certain level of public spending and are unwilling to pay taxes higher than a certain amount. If expected future primary budget surpluses necessary to keep the exchange rate fixed become too large, the policy regime changes. The regime switch is preceded by a speculative attack, or by multiple attacks, and coincides with a jump in the exchange rate. A speculative attack manifests itself by a sharp increase in the short-term nominal interest rate, not necessarily by a loss of foreign reserves. ${ }^{8}$ The regime

\footnotetext{
4 "Can Cardoso use financial chaos to reform Brazil?" The Economist, 24th September 1998.

${ }^{5}$ Foreign currency public debt or foreign currency private debt backed by the government has been a factor in numerous episodes other than Brazil.

6 "No peace for Brazil's president." The Economist, 21st January 1999.

${ }^{7}$ The exchange rate was not literally fixed in Brazil. The currency was devalued by small amounts according to a pre-announced schedule.

${ }^{8}$ Foreign reserves are an important variable in the first-generation model of Krugman (1979) and Flood
} 
switch occurs at a time of a fiscal emergency, after an unsustainable increase in public debt, when the government and the citizens recognize the need for inflation tax and some fiscal reform. At the time of the regime switch the government raises revenues by deflating public debt and transfer payments denominated in the domestic currency. After the regime switch monetary policy keeps interest rates on public debt low and stable thereby raising only small seigniorage revenues. This suggests that fiscal policy is active and monetary policy is passive.

\section{The model}

The framework of analysis is a dynamic stochastic model of a small open economy. Consider a small open economy with a government and many identical private agents who receive a constant endowment $Y$ of a single consumption good. The domestic price level $P$ and the foreign price level $P^{*}$ are linked by the law of one price. The model assumes that $P^{*}$ is constant and normalizes $P^{*}$ to unity. This implies that the exchange rate, defined as the price of one unit of the foreign currency in terms of the domestic currency, is equal to $P .{ }^{9}$ The economy takes exogenously the foreign nominal interest rate which is equal to the real interest rate.

\subsection{Private agents' optimization problem}

Private agents pay lump-sum taxes, hold one-period discount bonds $B$ denominated in the domestic currency, one-period discount bonds $B^{*}$ denominated in the foreign currency and domestic money $M$ that reduces transactions costs. The model assumes that $B$ and $M$ are each non-negative, issued by the government and held by private agents in the domestic economy. Private agents maximize

$$
E\left[\sum_{t=0}^{\infty} \beta^{t} \ln C_{t}\right]
$$

and Garber (1984). In that model a currency crisis takes place after foreign reserves have been exhausted.

${ }^{9}$ The model abstracts from the real exchange rate. Corsetti and Maćkowiak (2005) study dynamics of the real exchange rate in a model of a currency crisis in the passive monetary active fiscal regime. 
subject to

$$
\frac{B_{t}}{R_{t} P_{t}}+\frac{B_{t}^{*}}{\rho_{t}}+\frac{M_{t}}{P_{t}} \leq \frac{B_{t-1}}{P_{t}}+B_{t-1}^{*}+\frac{M_{t-1}}{P_{t}}+Y-\tau_{t}-C_{t}\left[1+\gamma f\left(V_{t}\right)\right]
$$

in every period. Here $R_{t}$ is the domestic gross nominal interest rate (that is, the inverse of the price of domestic currency discount bonds), $\rho_{t}$ is the foreign gross interest rate (that is, the inverse of the price of foreign currency discount bonds), $\tau_{t}$ denotes the real primary budget surplus of the government, $C_{t}$ denotes consumption of the single good, $V_{t} \equiv\left(C_{t} P_{t} / M_{t}\right)$ denotes velocity, $\gamma f\left(V_{t}\right)$ represents transactions costs per unit of consumption spending and $\gamma$ is a parameter satisfying $\gamma>0 .{ }^{10}$ In the model the evolution of the primary budget surplus $\tau_{t}$ is the only source of uncertainty. ${ }^{11}$

\subsection{The government budget constraint}

The government budget constraint is

$$
\frac{B_{t}}{R_{t} P_{t}}+\frac{F_{t}}{\rho_{t}}+\frac{M_{t}}{P_{t}}=\frac{B_{t-1}}{P_{t}}+F_{t-1}+\frac{M_{t-1}}{P_{t}}-\tau_{t}
$$

where $F_{t}$ denotes one-period foreign currency discount bonds issued by the government. Equation (1) should be interpreted broadly. In particular, governments have imperfectly indexed liabilities other than publicly traded bonds and money, for example pension commitments. There is evidence that even small changes in the price level can cause large changes in real value of such public liabilities. ${ }^{12}$ Furthermore, debt that was issued by a private agent but will be repaid by the government is sometimes not reported in official statistics. In the model there is no difference between public debt and privately issued debt that will be repaid by the government.

\subsection{First order conditions in the private agents' problem}

The first order conditions for a solution of the private agents' problem are as follows. The optimal choice of consumption reflects the difference, due to transactions costs, between the

\footnotetext{
${ }^{10}$ Feenstra (1986) shows equivalence between using money as an argument of a utility function and entering money into transactions costs that appear in a budget constraint.

${ }^{11}$ The specification with stochastic lump-sum taxes and logarithmic utility follows Leeper (1991) and Sims (1994).

${ }^{12}$ See Persson, Persson and Svensson (1998).
} 
marginal utility of consumption and the shadow value of the budget constraint of private agents $\lambda_{t}$

$$
C_{t}^{-1}=\lambda_{t}\left[1+\gamma f\left(V_{t}\right)+\gamma f^{\prime}\left(V_{t}\right) V_{t}\right]
$$

Given that $P^{*}$ is constant and given that the model abstracts from default risk, the first order condition with respect to $B^{*}$ is the same as for pricing a riskless bond

$$
\frac{1}{\rho_{t}}=\beta E_{t}\left(\frac{\lambda_{t+1}}{\lambda_{t}}\right)
$$

The first order condition with respect to $B$ is

$$
\frac{1}{R_{t}}=\beta E_{t}\left(\frac{\lambda_{t+1}}{\lambda_{t}} \frac{P_{t}}{P_{t+1}}\right)
$$

The first order condition with respect to $M$ includes a term reflecting transactions costs

$$
1-\gamma f^{\prime}\left(V_{t}\right) V_{t}^{2}=\beta E_{t}\left(\frac{\lambda_{t+1}}{\lambda_{t}} \frac{P_{t}}{P_{t+1}}\right) .
$$

Combining equations (4) and (5) yields a liquidity preference relation

$$
1-\gamma f^{\prime}\left(V_{t}\right) V_{t}^{2}=R_{t}^{-1}
$$

How money enters the model is inessential for the results. When one specializes to the family of bounded $f$ functions, $f\left(V_{t}\right) \equiv\left[V_{t} /\left(1+V_{t}\right)\right]^{\eta}$, where the parameter $\eta$ satisfies $\eta>0,{ }^{13}$ equation $(6)$ becomes

$$
\frac{M_{t}}{P_{t}}=\left\{\left[\gamma \eta\left(\frac{R_{t}}{R_{t}-1}\right)\right]^{\frac{1}{1+\eta}}-1\right\} C_{t} .
$$

The transversality condition is

$$
\lim _{T \rightarrow \infty} \beta^{T} E\left(\lambda_{T} \frac{B_{T}^{*}}{\rho_{T}}+\lambda_{T} \frac{B_{T}}{R_{T} P_{T}}+\lambda_{T} \frac{M_{T}}{R_{T} P_{T}}\right)=0 .
$$

Using equations (3), (4) and (5) and the following condition

$$
\lim _{T \rightarrow \infty} \beta^{T} E\left(\lambda_{T} \frac{F_{T}}{\rho_{T}}+\lambda_{T} \frac{B_{T}}{R_{T} P_{T}}+\lambda_{T} \frac{M_{T}}{R_{T} P_{T}}\right)=0,
$$

one obtains the solved-forward version of the government budget constraint (1)

$$
\frac{B_{t-1}+M_{t-1}}{P_{t}}+F_{t-1}=E_{t}\left\{\sum_{s=0}^{\infty} \frac{\beta^{s} \lambda_{t+s}}{\lambda_{t}}\left[\tau_{t+s}+\left(\frac{R_{t+s}-1}{R_{t+s}}\right) \frac{M_{t+s}}{P_{t+s}}\right]\right\} .
$$

\footnotetext{
${ }^{13}$ This specification of the $f$ function generalizes a specification in Sims (1994).
} 
The real value of public liabilities equals the present discounted value of expected primary budget surpluses plus the present discounted value of expected seigniorage revenues, where seigniorage revenues are equal to interest payments avoided by maintaining money balances.

Equation (8) can be used to illustrate the dichotomy of policy regimes due to Leeper (1991) and popular in the literature. Equation (8) plays a central role in determining the equilibrium price level in the passive monetary active fiscal regime. Given an exogenous path of budget surpluses the price level adjusts to satisfy equation (8). In the active monetary passive fiscal regime other equilibrium relations, equations (4) and (5), play a central role in determining the equilibrium price level. Equation (8) remains in the background since passive fiscal policy adjusts budget surpluses to make equation (8) hold.

Furthermore, equation (8) can be used to illustrate the difference between expected seigniorage revenues and fiscal consequences of unexpected changes in the price level. For example, it is perfectly possible that the term $\left(\frac{R_{t}-1}{R_{t}}\right) \frac{M_{t}}{P_{t}}$ is small in every period $t$ so that expected seigniorage revenues are small and, at the same time, stochastic fluctuations in the price level cause large fiscal gains and losses. Finally, equation (8) makes it clear why foreign reserves per se are not an important variable. What matters is how the sum of all net public liabilities compares with the sum of the present discounted value of primary budget surpluses and the present discounted value of seigniorage revenues.

Since the interest is in a regime switch that moves the economy far away from an initial steady state, it is important to obtain a nonlinear solution of the full model without resorting to approximation around a steady state. In order to keep the solution tractable it is necessary to abstract from some features that are straightforward to handle in models solved in approximate form, for example, the dynamics of current account. In the following attention is restricted to equilibria that arise if $\rho_{t}$ is equal to a constant $\rho$ such that $\rho=\beta^{-1}$, $\lambda_{t}$ is equal to a constant $\lambda$ and $B_{t}^{*}=F_{t}$ in every period $t$. In any such equilibrium uncovered interest parity holds

$$
\beta^{-1}=R_{t} E_{t}\left(\frac{P_{t}}{P_{t+1}}\right),
$$

that is, the expected return on domestic currency government bonds matches the inverse of the discount factor. Equation (9) follows from equation (4) given that $\lambda_{t}$ is equal to $\lambda$. 


\subsection{The policy regime before a switch}

Policy behavior is specified in terms of exogenous policy rules in the model. This is natural given that the interest is in modeling the behavior of private agents for a given policy behavior. Exogenous policy rules describe beliefs of private agents concerning what policy will do, regardless of why policy will do so. However, notice that policy behavior is modeled in terms of feedback rules that involve endogenous variables. This implies that there will be interactions between the behavior of private agents and policy variables. Furthermore, the date of the regime switch is endogenous in the model. ${ }^{14}$

Suppose the economy starts out in period $t=0$ with policy described by

$$
\left\{\begin{array}{c}
P_{t}=\bar{P} \\
\tau_{t}=\phi_{0}+\phi_{1}\left(\frac{B_{t-1}}{\bar{P}}+F_{t-1}\right)+\psi_{t}, \quad \psi_{t} \sim i i d N\left(0, \sigma^{2}\right), \quad t<T,
\end{array}\right.
$$

where the parameter $\phi_{0}$ satisfies $\phi_{0}<0$ and the parameter $\phi_{1}$ satisfies $1-\beta<\phi_{1}<1$. Policy for periods $t \geq T$ will be given below. The value of $T$ will be determined endogenously. Fixing the exchange rate $P$ at $\bar{P}$ is a form of active monetary policy. The restrictions on $\phi_{1}$ guarantee that the primary budget surplus rises with real value of public debt by more than enough to offset the increased public debt service. This means that the feedback rule in expression (10) constitutes passive fiscal policy. A higher value of the parameter $\phi_{1}$ implies a stronger systematic response of the primary budget surplus to public debt. The stochastic component of fiscal policy captures effects on revenues and expenditures of disturbances beyond the control of policymakers, or effects of capricious policy.

Expression (10) implies that in periods $t<T$ the economy is in the active monetary passive fiscal regime. It is straightforward to show that, if $T$ is set equal to infinity, the exchange rate $P_{t}$ will remain at $\bar{P}$ forever. Passive fiscal policy is critical to this conclusion. Passive fiscal policy implies that the government will always raise real taxes to pay for public debt and will never use inflation tax.

\footnotetext{
${ }^{14}$ Leeper (1991) and the subsequent literature as well as Krugman (1979) and the subsequent literature also postulate exogenous policy rules.
} 


\subsection{The policy regime switch rule}

The government budget constraint (1) and expression (10) with $T$ set equal to infinity imply that public debt follows a first-order stationary Gaussian autoregressive process with an autoregressive coefficient equal to $\beta^{-1}\left(1-\phi_{1}\right) \cdot{ }^{15}$ In this case, the variance of public debt is equal to the variance of the fiscal shock $\psi$ divided by $\beta^{2}-\left(1-\phi_{1}\right)^{2}$. This implies that the variance of public debt can be many times larger than the variance of the fiscal shock. ${ }^{16}$ Thus, even when fluctuations in revenues and expenditures are moderate, there will be states of nature such that large improvements in future primary budget surpluses will be required to keep the exchange rate fixed. However, if citizens want a certain level of government spending and are unwilling to pay taxes higher than a certain amount, there will be an upper bound on future primary budget surpluses. This political constraint implies that the active monetary passive fiscal regime will not be sustainable in some states of nature. ${ }^{17}$

When private agents form expectations, they recognize that the active monetary passive fiscal regime will not be sustainable in some states of nature. Suppose the government is expected to change the policy regime in a fiscal emergency, that is, at a time when expected future primary budget surpluses reach an upper bound. Formally, the government abandons the regime in expression (10) in period $T$ where $T$ is the first period $t$ in which (10) implies that

$$
\frac{B_{t-1}}{\bar{P}}+F_{t-1}-\tau_{t} \geq \bar{D}
$$

Thus a regime switch occurs in the first period in which, if policy continued to satisfy expression (10), the total amount of public debt minus the primary budget surplus would exceed an upper bound $\bar{D}$. Observe that $\bar{D}$ is in effect an upper bound on the expected

\footnotetext{
${ }^{15}$ With the exchange rate $P$ fixed at $\bar{P}$ forever there would be no distinction between domestic currency public debt $B$ and foreign currency public debt $F$.

${ }^{16}$ For example, when $\phi_{1}=0.07$ and $\beta=0.95$ the variance of public debt is equal to 25 times the variance of the fiscal shock $\psi$.

${ }^{17}$ Another way to motivate an upper bound on primary budget surpluses is with a feasibility constraint. Observe that a stationary Gaussian autoregressive process is unbounded. This implies that there will be states of nature such that the primary budget surplus required to keep the exchange rate fixed will be larger than real income $Y$.
} 
future primary budget surplus, since $E_{t}\left(\tau_{t+1}\right)$ is a monotonically increasing function of $\left(B_{t-1} / \bar{P}\right)+F_{t-1}-\tau_{t}{ }^{18}$ Thus expression (11) implies that expectations of the future, not the current level of public debt, trigger a regime switch. This accords well with the idea that expectations are critical to the dynamics of a currency crisis.

\subsection{The policy regime after a switch}

In periods $t \geq T$ monetary policy is passive and fiscal policy is active

$$
\left\{\begin{array}{c}
R_{t}=\bar{R} \\
\tau_{t}=\bar{\tau}+\psi_{t}=\theta_{0}+\theta_{1} R_{T-1}+\psi_{t}, \quad \psi_{t} \sim i i d N\left(0, \sigma^{2}\right), \quad t \geq T,
\end{array}\right.
$$

where $\bar{R} \geq \beta^{-1}$ and the parameter $\theta_{0}$ satisfies $\theta_{0}>0$. The Taylor principle fails to hold and the primary budget surplus follows a stochastic process independent of the level of public debt in periods $t \geq T .{ }^{19}$ Furthermore, the post-switch primary budget surplus $\bar{\tau}$ responds to the pre-switch interest rate $R_{T-1}$. This captures a variety of expectations private agents can have regarding the extent of fiscal reform coincident with the regime switch. Recall that in the real world the extent of fiscal reform varies from episode to episode. In the model $\theta_{1}>0$ corresponds to fiscal reform, $\theta_{1}<0$ corresponds to fiscal slippage and $\theta_{1}=0$ is a special case in which there is no feedback between the regime in periods $t<T$ and the regime in periods $t \geq T .^{20}$

\subsection{Currency composition of public debt}

The effects of currency composition of public debt can be illustrated as follows. Suppose that the government makes foreign currency public debt a constant fraction $\kappa$ of the total

\footnotetext{
${ }^{18}$ Specifically, expressions $(1)$ and $(10)$ with $T$ set equal to infinity imply that $E_{t}\left(\tau_{t+1}\right)=\phi_{0}+$ $\beta^{-1} \phi_{1}\left[\left(B_{t-1} / \bar{P}\right)+F_{t-1}-\tau_{t}\right]$.

${ }^{19}$ It is possible to include a more general active fiscal rule in the model. A more general active fiscal rule would allow the primary budget surplus to respond weakly to real value of public debt. That set-up would yield the same conclusions as the model in this paper calibrated with a higher value of the parameter $\theta_{0}$. Furthermore, see Corsetti and Maćkowiak (2004) for the analysis of a more general passive monetary policy rule. Their specification allows the nominal interest rate to react weakly to the rate of inflation.

${ }^{20}$ The political economy literature formalizes the idea that crises can be beneficial for fiscal reforms. See Drazen and Grilli (1993) and Zarazaga (1997).
} 
amount of public debt

$$
F_{t}=\kappa\left(\frac{B_{t}}{P_{t}}+F_{t}\right)
$$

where the parameter $\kappa$ satisfies $\kappa \in[0,1)$. The effects of changes in the parameter $\kappa$, for a given total amount of public debt and for a given sequence of shocks, are examined below. Solving the model with different values of $\kappa$ can be thought of as comparing two economies identical in every respect except for the currency composition of public debt, or as investigating the effects of an unanticipated one-time change in the currency composition of public debt in a single economy. The same interpretation applies to changes in other parameters of the model.

\subsection{Equilibrium}

A rational expectations equilibrium in this economy is a specification for the vector

$$
\left\{C_{t}, B_{t}, M_{t}, F_{t}, \tau_{t}, R_{t}, P_{t}\right\}_{t=0}^{\infty}
$$

such that: (i) $\left\{C_{t}, B_{t}, M_{t}, F_{t}\right\}_{t=0}^{\infty}$ solves the private agents' optimization problem in which private agents take as given $\left\{\tau_{t}, R_{t}, P_{t}\right\}_{t=0}^{\infty}$ and $\left\{Y, \rho, B_{-1}, M_{-1}, F_{-1}\right\}$; (ii) the government chooses $\left\{B_{t}, M_{t}, F_{t}, \tau_{t}, R_{t}, P_{t}\right\}_{t=0}^{\infty}$ taking as given equation (1), the private agents' optimality conditions and $\left\{Y, \rho, B_{-1}, M_{-1}, F_{-1}\right\}$; (iii) the solved-forward government budget constraint (8) holds.

\section{Analyzing the model}

This section analyzes the main mechanisms of the model. In the next section the model is solved numerically and simulated.

Consider a period $t$ such that $t<T$, that is, a period in which the active monetary passive fiscal regime is in place and $P_{t}=\bar{P}$. The government budget constraint (1), the feedback rule for $\tau_{t}$ in expression (10) and the policy rule for determining the currency composition of public debt (13) imply that

$$
\frac{B_{t}}{\bar{P}}=\left[\frac{R_{t}(1-\kappa)}{1-\kappa+\beta \kappa R_{t}}\right]\left[\left(1-\phi_{1}\right)\left(\frac{B_{t-1}}{\bar{P}}+F_{t-1}\right)-\phi_{0}-\psi_{t}-\left(\frac{M_{t}-M_{t-1}}{\bar{P}}\right)\right],
$$


and

$$
F_{t}=\left(\frac{\kappa R_{t}}{1-\kappa+\beta \kappa R_{t}}\right)\left[\left(1-\phi_{1}\right)\left(\frac{B_{t-1}}{\bar{P}}+F_{t-1}\right)-\phi_{0}-\psi_{t}-\left(\frac{M_{t}-M_{t-1}}{\bar{P}}\right)\right]
$$

Expressions (14) and (15) imply that when the nominal interest rate $R_{t}$ rises the total amount of public debt, $\left(B_{t} / \bar{P}\right)+F_{t}$, increases. The reasons are twofold. A lower price of domestic currency discount bonds implies that the government must issue a greater quantity of bonds, other things equal. Furthermore, when $R_{t}$ increases the demand for real money balances falls, that is, $\left(\frac{M_{t}-M_{t-1}}{\bar{P}}\right)<0$. This also implies that the government must issue a greater quantity of bonds, other things equal. In addition, expressions (14) and (15) imply that when the value of the parameter $\kappa$ rises the total amount of public debt decreases, so long as $R_{t}>\rho{ }^{21}$ If there is a non-zero probability of a currency crisis in period $t+1$, then $R_{t}>\rho$. See equation (9). The implications are as follows. If the probability of a currency crisis is zero, the currency composition of public debt does not affect the total amount of public debt. If the probability of a currency crisis is greater than zero, an increase in the value of $\kappa$ implies that the total amount of public debt decreases. Finally, expressions (14) and (15) imply that a stronger systematic policy response to public debt, i.e. a higher value of the parameter $\phi_{1}$, decreases public debt for a given value of the shock $\psi_{t}$. Therefore one can think of the parameter $\phi_{1}$ as a measure of the degree of fiscal reform in the active monetary passive fiscal regime.

Let $q_{t}$ denote the probability that a regime switch will occur in period $t+1$, conditional on information available in period $t$. Furthermore, define a variable $\widetilde{\psi}_{t}$ according to

$$
\widetilde{\psi}_{t}=\left(1-\phi_{1}\right)\left(\frac{B_{t}}{\bar{P}}+F_{t}\right)-\phi_{0}-\bar{D}
$$

where one can substitute expression $(14)$ for $\left(B_{t} / \bar{P}\right)$ and one can substitute expression (15) for $F_{t}$. Then the regime switch rule (11) implies that

$$
q_{t}=\operatorname{Pr}\left(\psi_{t+1} \leq \widetilde{\psi}_{t} \mid t\right)
$$

Expressions (14)-(16) imply that when the nominal interest rate $R_{t}$ rises the probability of the regime switch $q_{t}$ increases. Furthermore, when the value of $\kappa$ increases and the value of

\footnotetext{
${ }^{21} \mathrm{~A}$ change in the value of $\kappa$ does not affect the total amount of public debt when $R_{t}=\rho$.
} 
$\phi_{1}$ increases the probability of the regime switch $q_{t}$ falls. The reason is that changes in the nominal interest rate and changes in the values of the parameters $\kappa$ and $\phi_{1}$ affect the total amount of public debt and thereby affect how far the economy is from the point where a regime switch is triggered.

Next, observe that equation (7) implies that velocity $V_{t}$ is a monotonic function of the nominal interest rate $R_{t}$

$$
V_{t}=\left\{\left[\gamma \eta\left(\frac{R_{t}}{R_{t}-1}\right)\right]^{\frac{1}{1+\eta}}-1\right\}^{-1}
$$

Furthermore, equation (2) implies that consumption $C_{t}$ is a monotonic function of velocity

$$
C_{t}=\left\{\lambda\left[1+\gamma\left(\frac{V_{t}}{1+V_{t}}\right)^{\eta}+\gamma \eta\left(\frac{V_{t}}{1+V_{t}}\right)^{\eta-1} \frac{V_{t}}{\left(1+V_{t}\right)^{2}}\right]\right\}^{-1} .
$$

Substituting equation (17) into equation (18) yields an expression for consumption $C_{t}$ as a function of the nominal interest rate $R_{t}$. Consumption varies inversely with the nominal interest rate in equilibrium, because when the nominal interest rate is high more output is lost due to transactions costs. Substituting equation (18) into equation (7) yields an expression for real money balances $\left(M_{t} / P_{t}\right)$ as a function of the nominal interest rate $R_{t}$.

Consider now the period $t=T$, that is, the period of the regime switch. The exchange rate in period $T, P_{T}$, adjusts so that the real value of public liabilities equals the present discounted value of the sum of expected primary budget surpluses and expected seigniorage revenues. Specifically, $P_{T}$ adjusts so that equation (8)

$$
\frac{B_{T-1}+M_{T-1}}{P_{T}}+F_{T-1}=E_{T}\left\{\sum_{s=0}^{\infty} \beta^{s}\left[\tau_{T+s}+\left(\frac{R_{T+s}-1}{R_{T+s}}\right) \frac{M_{T+s}}{P_{T+s}}\right]\right\} .
$$

holds. It is straightforward to see that the present discounted value of expected seigniorage revenues depends only on the nominal interest rate in periods $t \geq T, \bar{R}$. Simply note

$$
E_{T}\left[\sum_{s=0}^{\infty} \beta^{s}\left(\frac{R_{T+s}-1}{R_{T+s}}\right) \frac{M_{T+s}}{P_{T+s}}\right]=(1-\beta)^{-1}\left(\frac{\bar{R}-1}{\bar{R}}\right) m(\bar{R}),
$$

where $m(\bar{R})$ is a monotonic function mapping the constant nominal interest rate $\bar{R}$ into a constant level of real money balances in periods $t \geq T$. Defining the variable $\Omega$ according to

$$
\Omega(\bar{R})=\left(\frac{\bar{R}-1}{\bar{R}}\right) m(\bar{R})
$$


yields the conclusion that the present discounted value of seigniorage revenues is equal to $(1-\beta)^{-1} \Omega$ and depends only on $\bar{R}$.

Next, the solved-forward government budget constraint (8) and the policy rule for $\tau_{t}$ in expression (12) imply that

$$
P_{T}^{-1}=\left(\frac{1}{B_{T-1}+M_{T-1}}\right)\left(\frac{\bar{\tau}}{1-\beta}+\psi_{T}+\frac{\Omega}{1-\beta}-F_{T-1}\right) .
$$

Consider a period $t$ such that $t<T$ and let $E_{t}\left(P_{t+1}^{-1} \mid\right.$ switch $)$ denote the expected value of $P_{t+1}^{-1}$ conditional on the regime switch taking place in period $t+1$ and conditional on information available in period $t$. Then equation (19) implies that

$$
E_{t}\left(P_{t+1}^{-1} \mid \text { switch }\right)=\left(\frac{1}{B_{t}+M_{t}}\right)\left(\frac{\bar{\tau}}{1-\beta}+\frac{\Omega}{1-\beta}-F_{t}\right) .
$$

Furthermore,

$$
P_{T}=\frac{B_{T-1}+M_{T-1}}{\left(\frac{\bar{\tau}}{1-\beta}+\psi_{T}\right)+\frac{\Omega}{1-\beta}-F_{T-1}} .
$$

In period $T$ the exchange rate adjusts so that equation (21) holds. ${ }^{22}$ Since period $T$ is a time of a fiscal emergency, parameter values will be chosen such that the exchange rate jumps up in period $T$, that is $P_{T}>\bar{P}$. In this case, the regime switch causes a decrease in the real value of domestic currency government liabilities $B$ and $M$. Observe that the term in brackets in the denominator on the right hand side of equation (21) is the present discounted value of expected primary budget surpluses. Equation (21) shows that the smaller is the present discounted value of primary budget surpluses, the larger is the jump in the exchange rate in period $T$. Furthermore, the smaller is the present discounted value of seigniorage revenues, the larger is the jump in the exchange rate in period $T$. Note also that foreign currency public debt enters with a negative sign in the denominator on the right hand side of equation (21). This implies that foreign currency public debt acts as leverage. If the amount of foreign currency public debt is large then the jump in the exchange rate is large, for given primary budget surpluses and seigniorage revenues.

Finally, uncovered interest parity (9) can be restated as

$$
\beta^{-1}=\bar{P} R_{t}\left[q_{t} E_{t}\left(P_{t+1}^{-1} \mid \text { switch }\right)+\left(1-q_{t}\right) \bar{P}^{-1}\right] .
$$

\footnotetext{
${ }^{22}$ Equation (21) holds in every period $t$ such that $t \geq T$, with the $T$ subscript replaced by the $t \geq T$ subscript.
} 
When the probability of the regime switch $q_{t}$ increases or $E_{t}\left(P_{t+1}^{-1} \mid\right.$ switch $)$ decreases, the nominal interest rate $R_{t}$ must go up. The expected return on domestic currency government bonds must match the return on foreign currency government bonds. However, observe that ex post returns on domestic currency government bonds can be different from the return on foreign currency government bonds. In fact, if the probability of a currency crisis is greater than zero but a currency crisis does not occur, the ex post return on domestic currency government bonds will be greater than the return on foreign currency bonds. This is why domestic currency government bonds are different in the model from foreign currency government bonds.

Considering the equations displayed in this section helps develop intuition regarding determinacy of equilibrium in the model. In a period $t$ such that $t<T$, consider an economy in which the parameter $\theta_{1}$ satisfies $\theta_{1}=0$. Suppose that the nominal interest rate $R_{t}$ increases. This makes the total amount of public debt go up. With more public debt held by private agents the probability of the regime switch increases and the expected size of the jump in the exchange rate increases. But when the probability of the regime switch increases and the expected size of the jump in the exchange rate increases, the nominal interest rate goes up by uncovered interest parity. The dynamic is circular which suggests that there can exist multiple equilibria. In particular, there can exist an equilibrium in which the nominal interest rate is low and the probability of a currency crisis is low and there can exist an equilibrium in which the nominal interest rate is high and the probability of a currency crisis is high. A currency crisis can be a self-fulfilling event. Next, consider an economy in which the parameter $\theta_{1}$ is positive and suppose again that the nominal interest rate $R_{t}$ increases. This still makes the total amount of public debt go up. However, now the expected size of the jump in the exchange rate can decrease because the government is expected to undertake fiscal reform in the event of the regime switch. The circularity is eliminated.

The model suggests that macroeconomic stability in the active monetary passive fiscal regime, when there exists a possibility of a switch to the passive monetary active fiscal regime, depends on expectations about what will happen after the switch. The reasons are twofold. Since the active monetary passive fiscal regime is not sustainable in all states 
of nature, private agents need to form expectations not only about policy in the current active monetary passive fiscal regime but also about policy in the case if the current regime is abandoned. Furthermore, the behavior of private agents can cause interest rates on public debt to rise and this can take the economy to the brink of a regime switch. Only policy commitment concerning what will happen after the regime switch can eliminate the speculative dynamics of public debt as possible equilibria. The subsequent section provides a detailed numerical analysis of determinacy of equilibrium and other features of the model.

\section{Solving and simulating the model}

This section discusses numerical solutions of the model for a variety of different parameter values. The numerical solution procedure consists of the following steps. In the first step parameter values are chosen and a value for the vector of initial conditions $\left\{B_{-1}, M_{-1}, F_{-1}\right\}$ is chosen. In the second step $N$ realizations of the stochastic process for $\left\{\psi_{t}\right\}_{t=0}^{t=\widehat{T}}$ are simulated. In the third step the solution for

$$
\left\{C_{t}, B_{t}, M_{t}, F_{t}, \tau_{t}, R_{t}, P_{t}, q_{t \mid t<T}, E_{t \mid t<T}\left(P_{t+1}^{-1} \mid \text { switch }\right)\right\}_{t=0}^{t=\widehat{T}}
$$

is computed and the period of the regime switch $T$ is recorded, for each of the $N$ realizations of the stochastic process for $\left\{\psi_{t}\right\}_{t=0}^{t=\widehat{T}} .{ }^{23}$ The exercise is repeated with the same $N$ realizations of the stochastic process for $\left\{\psi_{t}\right\}_{t=0}^{t=\widehat{T}}$ and with different parameter values. See Appendix A for details of the numerical solution procedure.

The presentation of the results is organized around a benchmark economy. Parameter values for the benchmark economy are motivated by the main features of the currency crisis in Brazil. Afterwards the effects of changes in the parameter values are examined. The data indicate that net debt of the federal government in Brazil was between 30 and 40 percent of GDP in the two years prior to the currency crisis and in the two years after the currency crisis. The data almost certainly understate significantly the true indebtedness of the public sector in Brazil, since the data do not include non-traded liabilities of the federal government or liabilities of state governments. Therefore, parameter values are chosen such

\footnotetext{
${ }^{23}$ The notation $q_{t \mid t<T}$ and $E_{t \mid t<T}\left(P_{t+1}^{-1} \mid\right.$ switch $)$ indicates that the variables $q_{t}$ and $E_{t}\left(P_{t+1}^{-1} \mid\right.$ switch are only defined in periods $t<T$.
} 
that public debt in the model, $\frac{B_{t}}{P_{t}}+F_{t}$, is higher than in the data and fluctuates between

40 and 70 percent of real income. Based on this reasoning, $\frac{B_{-1}}{\bar{P}}+F_{-1}$ is set equal to $0.45, \bar{D}$ is set equal to $0.6, \sigma$ is set equal to $0.04, \phi_{0}$ is set equal to -0.02 and $\phi_{1}$ is set equal to 0.07. $\bar{P}$ is set equal to 1 . After the amount of public debt in the model has been chosen, the parameters $\theta_{0}$ and $\theta_{1}$ are set such that the present discounted value of primary budget surpluses is approximately as large as the amount of public debt. In addition, in the benchmark economy the parameter $\theta_{1}$ is set such that there is a unique equilibrium. This reasoning yields $\theta_{0}=0.0135$ and $\theta_{1}=0.012$. The parameter $\kappa$ is set equal to 0.5 in the benchmark economy, which is approximately the value in the data from Brazil until a few months before the currency crisis. ${ }^{24}$ The parameter $\bar{R}$ is set equal to 1.05 , which was approximately the average gross short-term nominal interest rate in the two years after the currency crisis in Brazil. ${ }^{25}$ The parameter $\rho$ is also set equal to 1.05 , which was approximately the average gross interest rate on the dollar denominated Brazilian treasury bill during the two years prior to the currency crisis. The parameters $\gamma$ and $\eta$ are chosen such that the ratio $\left(M_{t} / P_{t} Y\right)$ in the model is approximately the same as the average ratio of the monetary base to nominal GDP in the data. This yields $\gamma=1 / 25$ and $\eta=24 .^{26}$

\subsection{Determinacy of equilibrium}

Figure 2 illustrates the behavior of the benchmark economy. This figure plots the equilibrium values of the variables in the model in period $t<T$ as a function of the initial amount of public debt, $\frac{B_{t-1}}{P}+F_{t-1}$. One can think of the figure as a snapshot of the solution of the dynamic model in a period in which the active monetary passive fiscal regime is in place. There is a unique equilibrium. The nominal interest rate $R_{t}$, the probability of the regime switch $q_{t}$, and the inverse of $E_{t}\left(P_{t+1}^{-1} \mid\right.$ switch $)$ increase as the initial amount of public debt rises. Furthermore, the end-of-period amount of public debt, $\frac{B_{t}}{P}+F_{t}$, increases. In this particular case, since $\kappa=0.5$, domestic currency public debt is equal to foreign currency

\footnotetext{
${ }^{24}$ The value of $\kappa$ in the data from Brazil increased to about 0.9 in the few months immediately prior to the currency crisis. See Panel B in Figure 1. The effects of changes in the parameter $\kappa$ are examined below.

${ }^{25}$ This assumes that a single period in the model is a quarter.

${ }^{26}$ In addition, $N$ is set equal to $250, \widehat{T}$ is set equal to 200 and $M_{-1}$ is set equal to a value implied by the model given that $R_{-1}=\rho$.
} 
public debt. Finally, money holdings fall and consumption falls as the initial amount of public debt rises. ${ }^{27}$

Consider how the behavior of the economy in period $t<T$ changes when the parameter $\theta_{1}$ decreases. The top row in Figure 3 illustrates the behavior of the economy with $\theta_{1}=$ 0.006 , that is, the parameter $\theta_{1}$ decreases by 50 percent relative to the benchmark economy. The bottom row in Figure 3 illustrates the behavior of the economy with $\theta_{1}=0.001$. Both economies depicted in Figure 3 have a unique equilibrium if the initial amount of public debt is low and if the initial amount of public debt is high. Furthermore, both economies have multiple equilibria if the initial amount of public debt is in an intermediate range. In fact, there are then three equilibria: an equilibrium in which the probability of a currency crisis $q_{t}$ is approximately zero, an equilibrium in which $q_{t}$ is approximately one and an equilibrium in which $q_{t}$ is in an intermediate range. As $\theta_{1}$ decreases, the range of the initial conditions associated with indeterminacy of equilibrium widens. Note that the same initial conditions can be consistent with either the regime switch with probability one or continuation of the status quo with probability one. This implies that self-fulfilling beliefs of private agents can determine whether the regime switch occurs.

It is interesting to ask how an economy with multiple equilibria appears to an outside observer. In every period $t<T$ one equilibrium outcome is realized. In period $t+1$ either a regime switch occurs or a regime switch does not occur. In the former case there is a unique equilibrium outcome from then on. In the latter case there are again multiple equilibrium outcomes, so long as public debt remains in the range associated with multiplicity of equilibria.

The results show that a sufficient value of the parameter $\theta_{1}$ guarantees that equilibrium is unique. When the parameter $\theta_{1}$ is large enough, the expected magnitude of the currency crisis fails to rise sufficiently in response to a high nominal interest rate for that high nominal interest rate to be a viable equilibrium. The value of the parameter $\theta_{1}$ can reflect the extent of explicit fiscal reform undertaken in response to the currency crisis, where explicit fiscal reform is, for example, the decrease in pension benefits in response to the currency crisis in Brazil. The value of the parameter $\theta_{1}$ can also reflect the extent of implicit fiscal reform

\footnotetext{
${ }^{27}$ In deriving the solutions depicted in Figures 2-4 the value of $\psi_{t}$ is set equal to $-\sigma$.
} 
that occurs in response to the currency crisis without legislative action, for example, the decreases in the real value of government transfer payments in Korea, Mexico and Turkey.

\subsection{Currency composition of public debt}

The discussion from this point focuses on parameter values such that there is a unique equilibrium. Figure 4 illustrates how the behavior of the economy in period $t<T$ changes when the parameter $\kappa$ is different than in the benchmark economy. Recall from Section 4 that an increase in the parameter $\kappa$ has two effects. When the parameter $\kappa$ rises the total amount of public debt falls. Therefore the probability of the regime switch decreases and the nominal interest rate decreases. Furthermore, when the parameter $\kappa$ rises, the government's leverage increases. Therefore the expected size of the jump in the exchange rate increases, the nominal interest rate increases and the probability of the regime switch increases. Figure 4 shows the interaction of the two effects in equilibrium. The latter effect implies that the expected size of the jump in the exchange rate is always at least at large in an economy with a high value of $\kappa$ compared to an economy with a low value of $\kappa$. The former effect implies that the probability of the regime switch can be lower in an economy with a high value of $\kappa$ than in an economy with a low value of $\kappa$. In particular, when the initial amount of public debt is large the probability of the regime switch is lower in an economy with a high value of $\kappa$ than in an economy with a low value of $\kappa$.

What do the two effects imply for the simulated data? Figure 5 displays histograms of data simulated using the model for an economy with a low value of $\kappa$ and for an economy with a high value of $\kappa$. When the parameter $\kappa$ increases the regime switch gets delayed, that is, the mean value of $T$ in the simulated data rises. The reason is that the presence of foreign currency public debt makes the total amount of public debt grow more slowly. This implies that more time elapses before public debt reaches the point where the regime switch is triggered. Furthermore, when the parameter $\kappa$ increases the size of the jump in the exchange rate rises, that is, the mean value of $P_{T}$ in the simulated data increases. The reason is that foreign currency public debt acts as leverage. Figure 6 depicts four examples of data simulated using the model. Each simulation uses the same shocks. Compare the economy in which most public debt is denominated in the domestic currency (column 1) to 
the economy in which most public debt is denominated in the foreign currency (column 2). The economy in column 1 sees a larger expansion of public debt and experiences a currency crisis earlier compared to the economy in column 2. The model predicts that economies identical in every respect except for the currency composition of public debt will see different paths of macroeconomic variables. The reason is that a change in the currency composition of public debt affects private agents' expectations regarding the probability and the size of the jump in the exchange rate. In particular, a currency crisis gets delayed when the share of foreign currency public debt is large.

Furthermore, issuing foreign currency public debt can act as a substitute for fiscal reform. Compare the economies depicted in columns 2 and 3 of Figure 6. Both economies experience a currency crisis at about the same time and later than the economy in column 1 . The reason why the currency crisis is delayed in the economy in column 3 is very different from the reason why the currency crisis is delayed in the economy in column 2 . In the economy in column 3 there is more fiscal reform when the active monetary passive fiscal regime is in place, that is, the parameter $\phi_{1}$ is relatively high. In the economy in column 2, a greater share of public debt is denominated in the foreign currency. It is striking that a change in the currency composition of public debt can produce as much delay as fiscal reform. Notice also that the size of a currency crisis, when a currency crisis finally occurs, is largest in the economy in column 2 in which the government is most leveraged.

The model predicts that a fixed exchange rate in an economy where a sizable fraction of public debt is denominated in a foreign currency is more likely to survive relatively mild shocks and afterwards collapse with a bang after a truly bad shock. The model also indicates that more vigorous fiscal reform when the fixed exchange rate is in place delays the date of the currency crisis. In the real world fiscal reform is costly whereas the alternative of borrowing mostly in a foreign currency is costless in the immediate future. If anything, fiscal accounts "improve" as the total amount of public debt falls. Furthermore, the alternative of borrowing mostly in a foreign currency is associated with only a possibility of a currency crisis, perhaps in a distant future. Therefore, the model suggests why policymakers with a high discount rate can be attracted to borrowing in a foreign currency. 


\subsection{Seigniorage revenues}

Column 4 in Figure 6 illustrates the effects of changes in the nominal interest rate in the passive monetary active fiscal regime, $\bar{R}$. The economy in column 4 has a larger value of $\bar{R}$ and therefore the present discounted value of seigniorage revenues is larger than in the economy in column $3 .^{28}$ This implies that the economy in column 4 experiences a smaller jump in the exchange rate, but at the expense of an upward drift in the exchange rate after the currency crisis. This comparison illustrates the trade-off between the one-time jump in the exchange rate coincident with the regime switch and the chronic exchange rate depreciation after the regime switch. Notice also that the economies in columns 1-3 do not experience an increase in seigniorage revenues after the currency crisis.

\subsection{Suddenness of the regime switch}

The model suggests that, even when equilibrium is unique, a currency crisis will be sudden and difficult to predict. For example, the economy depicted in column 3 in Figure 6 experiences a one-time spike in the nominal interest rate and afterwards a currency crisis occurs. Furthermore, consider the histograms of the simulated data in Figure 5. Almost all observations on the probability of the regime switch $q_{t}$ are near zero and, in addition, some observations are near one. This implies that a currency crisis can be sudden, even if it is due to fundamentals and is unique equilibrium phenomenon. Furthermore, it can be difficult to predict a currency crisis more than a single period in advance. A currency crisis preceded by smoothly rising interest rates or by a prolonged period with high and stable rates is unlikely to happen. The suddenness is caused by the same dynamic of public debt that produces multiple solutions for some parameter values. Once the probability of the regime switch is even a little bit different from zero, interest rates rise swiftly precipitating the regime switch.

The model also suggests what makes a currency crisis inevitable. Recall from expression (10) that the fiscal shock $\psi$ is a Gaussian random variable. Since a Gaussian random variable has unbounded support, a regime switch in the model occurs with probability one in finite

\footnotetext{
${ }^{28}$ The variable "seigniorage" plotted in Figure 6 is computed consistent with equation (8) as $\left(\frac{R_{t}-1}{R_{t}}\right) \frac{M_{t}}{P_{t}}$ in every period $t$.
} 
time. In this sense the active monetary passive fiscal regime is unsustainable and a currency crisis is inevitable. However, it is possible to solve the model under the specification that the fiscal shock $\psi$ has bounded support. If in addition the parameter $\bar{D}$ is a large number, then there will be no currency crisis for some realizations of the stochastic process for $\left\{\psi_{t}\right\}$. That policy is expected to switch to the passive monetary active fiscal regime in some states of nature does not imply per se that a regime switch must occur in equilibrium. This is a difference between this model and the first generation model of Krugman (1979) and Flood and Garber (1984) in which policy behavior implies that a currency crisis is inevitable.

\section{Concluding observations}

The model developed in this paper emphasizes coordination of monetary policy and fiscal policy and the dynamics of private agents' expectations in the presence of uncertainty. Many features that play a central role in the model have played a central role in recent currency crises. These features include small seigniorage revenues, currency composition of public liabilities and fiscal reform.

Policy discussions surrounding a currency crisis often emphasize that insufficient fiscal reform had taken place before a successful speculative attack occurred. This model suggests that how much fiscal reform takes place after a successful speculative attack is more important for stability of a fixed exchange rate, in the sense of ruling out self-fulfilling currency crises.

The model focuses on a particular form of active monetary policy. However, the insights from the model apply to other forms of active monetary policy. For example, the model guides our intuition about a possible crisis scenario in a monetary union. It has been pointed out that explicit default on public debt seems more costly than restarting a national currency (Sims, 1999). Furthermore, a formal change of the status quo seems more costly than creating "something akin to a second currency (...) - not a currency by name, perhaps, but by function." (Uhlig, 2002, p. 25). Whether the former or the latter scenario is expected, this model suggests that the dynamics of a possible crisis will depend on what policy is expected to do after the monetary union collapses or is suspended. 
The model can be extended in a variety of directions. It will be interesting to endogenize the policy behavior assumed in the model, for example based on a political economy model. It will also be interesting to extend the model to include real variables, for example by introducing firms, production and a financial friction. In addition, it will be interesting to collect econometric evidence concerning policy regime switches. 


\section{A Numerical solution procedure}

The numerical solution procedure is as follows. In any period $t$ such that a regime switch has not taken place prior to period $t$ the first step is to check, using expression (11) and taking as given $\left\{B_{t-1}, M_{t-1}, F_{t-1}\right\}$ and $\psi_{t}$, whether a regime switch occurs in period $t$. Suppose that a regime switch does not occur, that is, suppose that $t$ satisfies $t<T$. Then $P_{t}=\bar{P}$ and $\tau_{t}$ is given by expression (10). Consider equation (22). One substitutes equation (20) for $E_{t}\left(P_{t+1}^{-1} \mid\right.$ switch) in equation (22) and one substitutes equation (16) for $q_{t}$ in equation (22). Observe that, according to equation (16), the probability of the regime switch is given

by $q_{t}=\Phi\left[\frac{\widetilde{\psi}_{t}\left(R_{t}\right)}{\sigma}\right]$, where $\Phi$ denotes the standard Gaussian cumulative distribution function and $\widetilde{\psi}_{t}\left(R_{t}\right)$ indicates that $\widetilde{\psi}_{t}$ is a function of $R_{t}$. Thus equation (22) becomes a nonlinear equation in a single variable, $R_{t}$. One solves equation (22) and afterwards one solves for the other variables of the model given $R_{t}$. The solution of equation (22) makes use of the erf function in Matlab. Specifically,

$$
q_{t}=\frac{1}{2}\left\{1+\operatorname{erf}\left[\frac{\widetilde{\psi}_{t}\left(R_{t}\right)}{\sigma \sqrt{2}}\right]\right\} .
$$

Given $R_{t}$, equations (7) and (18) yield $M_{t}$ and $C_{t}$, equations (14)-(15) yield $B_{t}$ and $F_{t}$, equation (20) yields $E_{t}\left(P_{t+1}^{-1} \mid\right.$ switch) and equation (22) yields $q_{t}$. This yields

$$
\left\{C_{t}, B_{t}, M_{t}, F_{t}, \tau_{t}, R_{t}, P_{t}, q_{t}, E_{t}\left(P_{t+1}^{-1} \mid \text { switch }\right)\right\}
$$

Next, suppose that $t$ satisfies $t \geq T$. Then $R_{t}=\bar{R}$ and $\tau_{t}=\bar{\tau}+\psi_{t}$. Furthermore, equation (21) determines $P_{t}$, equations (7) and (18) determine $M_{t}$ and $C_{t}$ given $P_{t}$ and equations (1) and (13) determine $B_{t}$ and $F_{t}$ given $P_{t}$. This yields $\left\{C_{t}, B_{t}, M_{t}, F_{t}, \tau_{t}, R_{t}, P_{t}\right\}$.

\section{B Data sources}

Data on federal debt in Brazil, at monthly frequency, are taken from the website of Banco Central do Brasil, http://www.bcb.gov.br. All other data are taken from Datastream: the monetary base is the series BRI14...A, foreign reserves are the series BRI11...A, the central bank's net claims on treasury are set equal to the series BRI12A..A minus the series BRI16D..A, the exchange rate is the series BRXRUSD., the money market interest rate is the series BRI60B.., nominal GDP is the series 
BRGDP...A, the interest rate on dollar denominated treasury bills is the series BRI60C.F. All the series are at monthly frequency except for nominal GDP, which is quarterly. Seigniorage revenues

in a given quarter $t$ are computed, consistent with equation (8), as $\left(\frac{R_{t}-1}{R_{t}}\right) \frac{M_{t}}{G D P_{t}}$ where $R_{t}$ is the money market interest rate, $M_{t}$ is the monetary base and $G D P_{t}$ is nominal GDP.

\section{References}

[1] Andolfatto, David and Paul Gomme (2003): "Monetary Policy Regimes and Beliefs." International Economic Review, 44, 1-30.

[2] Burnside, Craig, Martin Eichenbaum and Sergio Rebelo (2001): "Prospective Deficits and the Asian Currency Crisis.” Journal of Political Economy, 109, 1155-97.

[3] Burnside, Craig, Martin Eichenbaum and Sergio Rebelo (2005): “Government Finance in the Wake of Currency Crises." Working paper, Duke University and Northwestern University.

[4] Calvo, Guillermo A. (1988): "Servicing the Public Debt: the Role of Expectations." American Economic Review, 78, 647-661.

[5] Corsetti, Giancarlo and Bartosz Maćkowiak (2004): "Fiscal Imbalances and the Dynamics of Currency Crises." European Economic Review, forthcoming.

[6] Corsetti, Giancarlo and Bartosz Maćkowiak (2005): "A Fiscal Perspective on Currency Crises and Original Sin." In "Other People's Money: Debt Denomination and Financial Instability in Emerging Market Economies." Edited by Barry Eichengreen and Ricardo Hausmann. The University of Chicago Press, Chicago and London.

[7] Daniel, Betty C. (2001): "A Fiscal Theory of Currency Crises.” International Economic Review, 42, 969-88.

[8] Davig Troy and Eric M. Leeper (2005): "Fluctuating Macro Policies and the Fiscal Theory." Working paper, The College of William and Mary and Indiana University.

[9] Davig Troy, Eric M. Leeper, and Hess Chung (2005): "Monetary and Fiscal Policy Switching." Working paper, The College of William and Mary and Indiana University. 
[10] Drazen, Allan and Vittorio Grilli (1993): "The Benefit of Crises for Economic Reforms." American Economic Review, 83, 598-607.

[11] Feenstra, Robert C. (1986): "Functional Equivalence Between Liquidity Costs and the Utility of Money." Journal of Monetary Economics, 17, 271-291.

[12] Flood, Robert P. and Peter M. Garber (1984): "Collapsing Exchange Rate Regimes: Some Linear Examples." Journal of International Economics, 17, 1-13.

[13] Krugman, Paul R. (1979): "A Model of Balance of Payments Crises.” Journal of Money, Credit and Banking, 11, 311-325.

[14] Leeper, Eric (1991): “Equilibria Under 'Active' and 'Passive' Monetary and Fiscal Policies." Journal of Monetary Economics, 27, 129-147.

[15] Obstfeld, Maurice (1994): "The Logic of Currency Crises." Cahiers Economiques et Monétaires, 43, 189-213.

[16] Persson, Mats, Torsten Persson and Lars E. O. Svensson (1998): "Debt, Cash Flow and Inflation Incentives: A Swedish Example." In "The Debt Burden and its Consequences for Monetary Policy." Edited by Guillermo A. Calvo and Mervin King. St. Martin's Press, New York.

[17] Sims, Christopher A. (1994): "A Simple Model for Study of the Determination of the Price Level and the Interaction of Monetary and Fiscal Policy." Economic Theory, 4, 381-399.

[18] Sims, Christopher A. (1997): "Fiscal Foundations of Price Stability in Open Economies." Working paper, Yale University.

[19] Sims, Christopher A. (1999): "The Precarious Fiscal Foundations of EMU." De Economist, 147, 415-36.

[20] Taylor, John B. (1993): "Discretion versus Policy Rules in Practice." CarnegieRochester Conference Series on Public Policy, 39, 195-214. 
[21] Uhlig, Harald (2002): "One Money, But Many Fiscal Policies in Europe: What Are the Consequences?" Working paper, Humboldt University Berlin.

[22] Woodford, Michael (1995): "Price-Level Determinacy Without Control of a Monetary Aggregate." Carnegie-Rochester Conference Series on Public Policy, 43, 1-46.

[23] Woodford, Michael (2001): "Fiscal Requirements for Price Stability." Journal of Money, Credit and Banking, 33, 669-728.

[24] Zarazaga, Carlos (1997): "Recurrent Hyperinflations in a Dynamic Game with Imperfect Monitoring in the Appropriation of Seigniorage." Working paper, Federal Reserve Bank of Dallas. 
Table 1: Currency crises in Korea (1997), Mexico (1994) and Turkey (2001)

\begin{tabular}{|c|c|c|c|}
\hline & Korea & Mexico & Turkey \\
\hline Size of devaluation ${ }^{\dagger}$, in percent & 46 & 41 & 44 \\
\hline Fiscal imbalance*, in percent of GDP & 24 & 15 & 18.2 \\
\hline Fiscal gains from seigniorage, in percent of GDP & 1.1 & 1.8 & 1.7 \\
\hline $\begin{array}{l}\text { Fiscal gains from a decrease in the real value of } p \\
\text { and transfer payments, in percent of GDP }\end{array}$ & 12.4 & 20.1 & 8.2 \\
\hline Fiscal gains from reform ${ }^{\#}$, in percent of GDP & 9.9 & -3.7 & 1.5 \\
\hline
\end{tabular}

${ }^{\dagger}$ Percentage decrease in the value of the domestic currency relative to the dollar in the quarter after the abandonment of the fixed exchange rate.

${ }^{*}$ The fiscal cost of the bank bailout in each country.

\#The sum of explicit fiscal reform (an increase in the present discounted value of primary budget surpluses due to legislative action)

and implicit fiscal reform (an increase in the present discounted value of primary budget surpluses due to currency devaluation, without legislative action).

Sources: The first row is based on data from International Financial Statistics. The rest is based on Table 7 in Burnside,

Eichenbaum and Rebelo (2005). 
Figure 1: The currency crisis in Brazil, January 1999
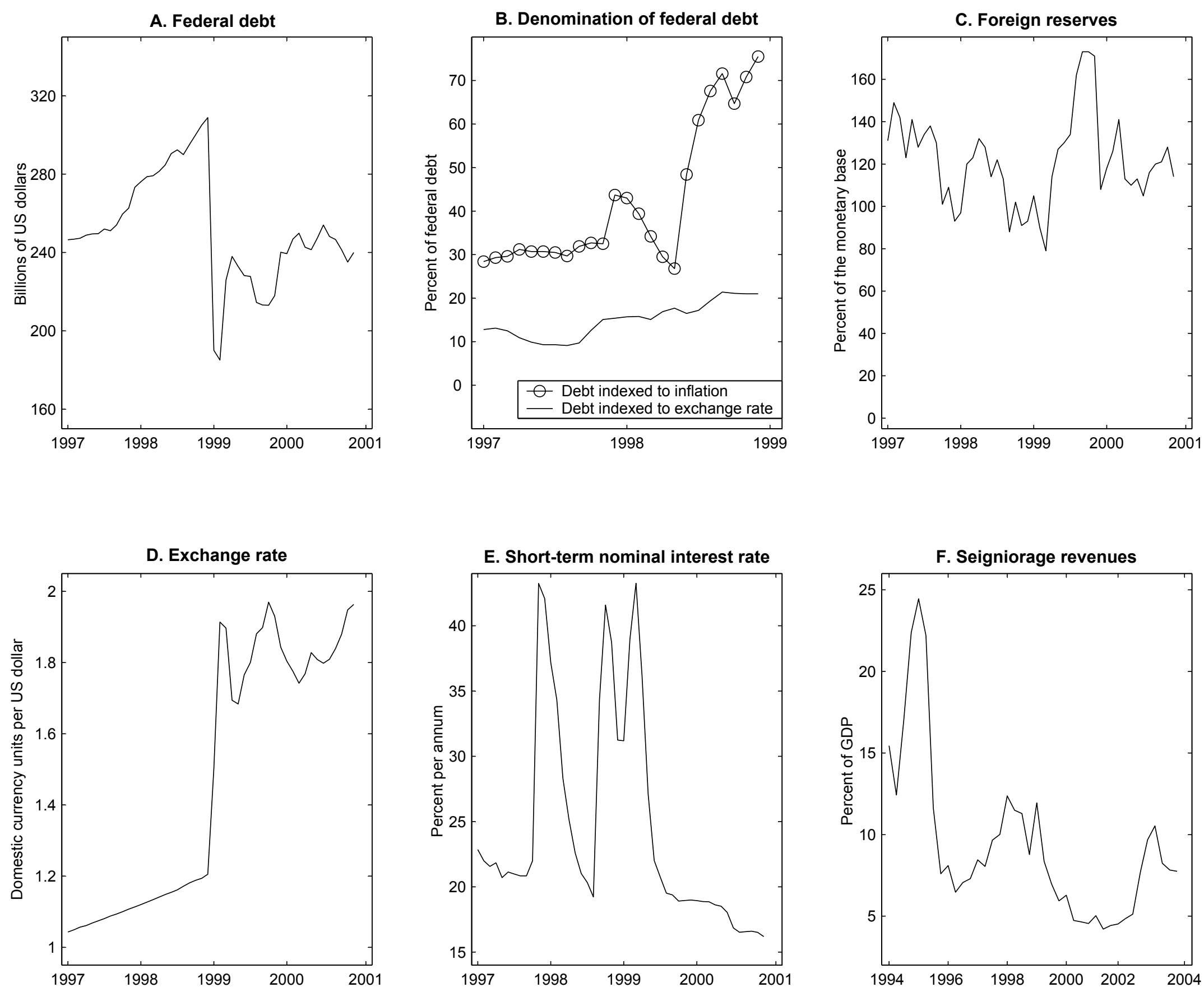

Note: See Appendix B for data sources. 
Figure 2: The benchmark economy
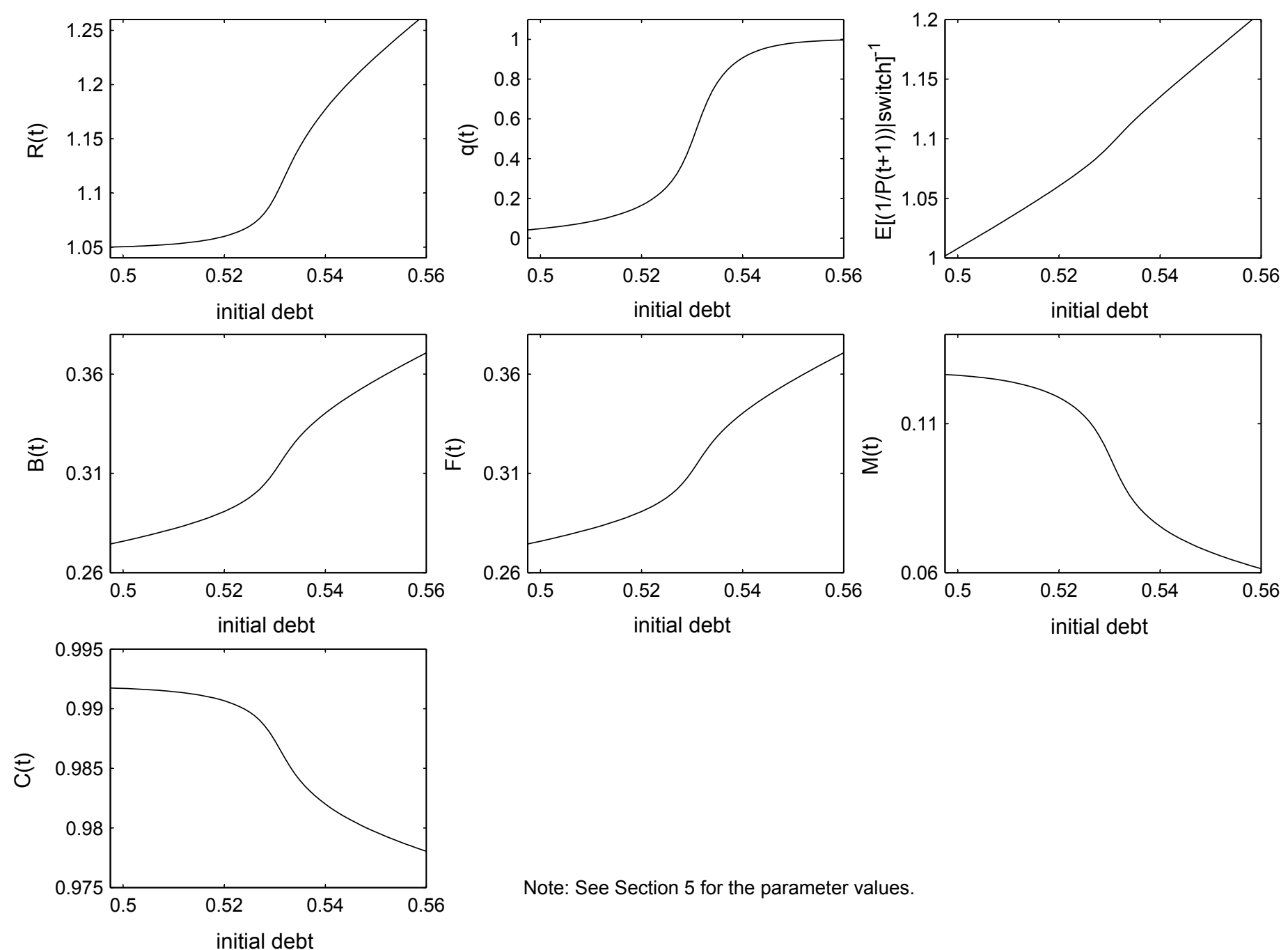

Note: See Section 5 for the parameter values. 
Figure 3: The effects of changes in the parameter $\theta_{1}$
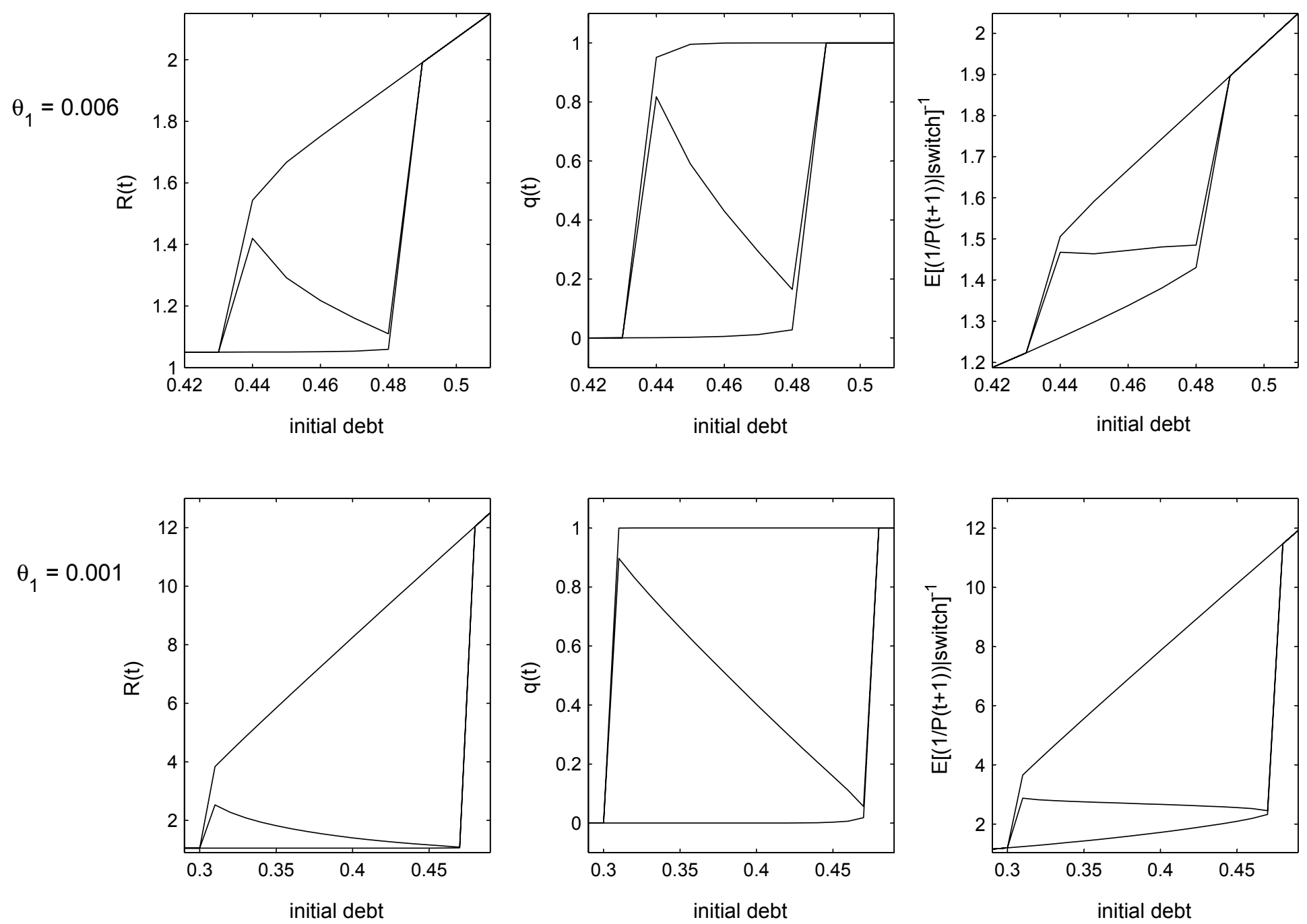

Note: The parameter values are the same as in the benchmark economy except as indicated to the left of each row. 
Figure 4: The effects of changes in the parameter $\kappa$
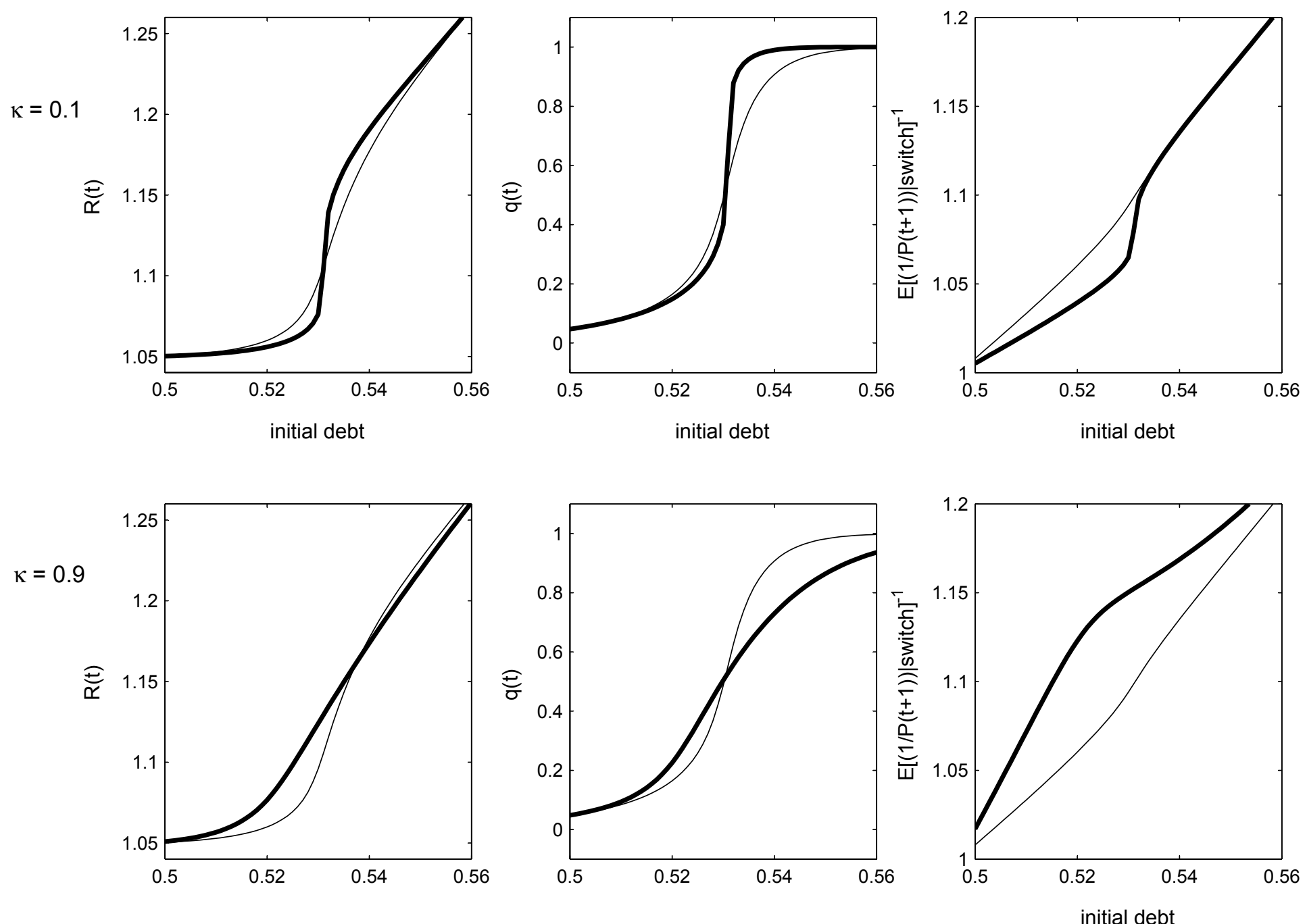

Note: Thin lines reproduce the solution for the benchmark economy.

Thick lines are drawn for the 
Figure 5: Histograms of data simulated from the model
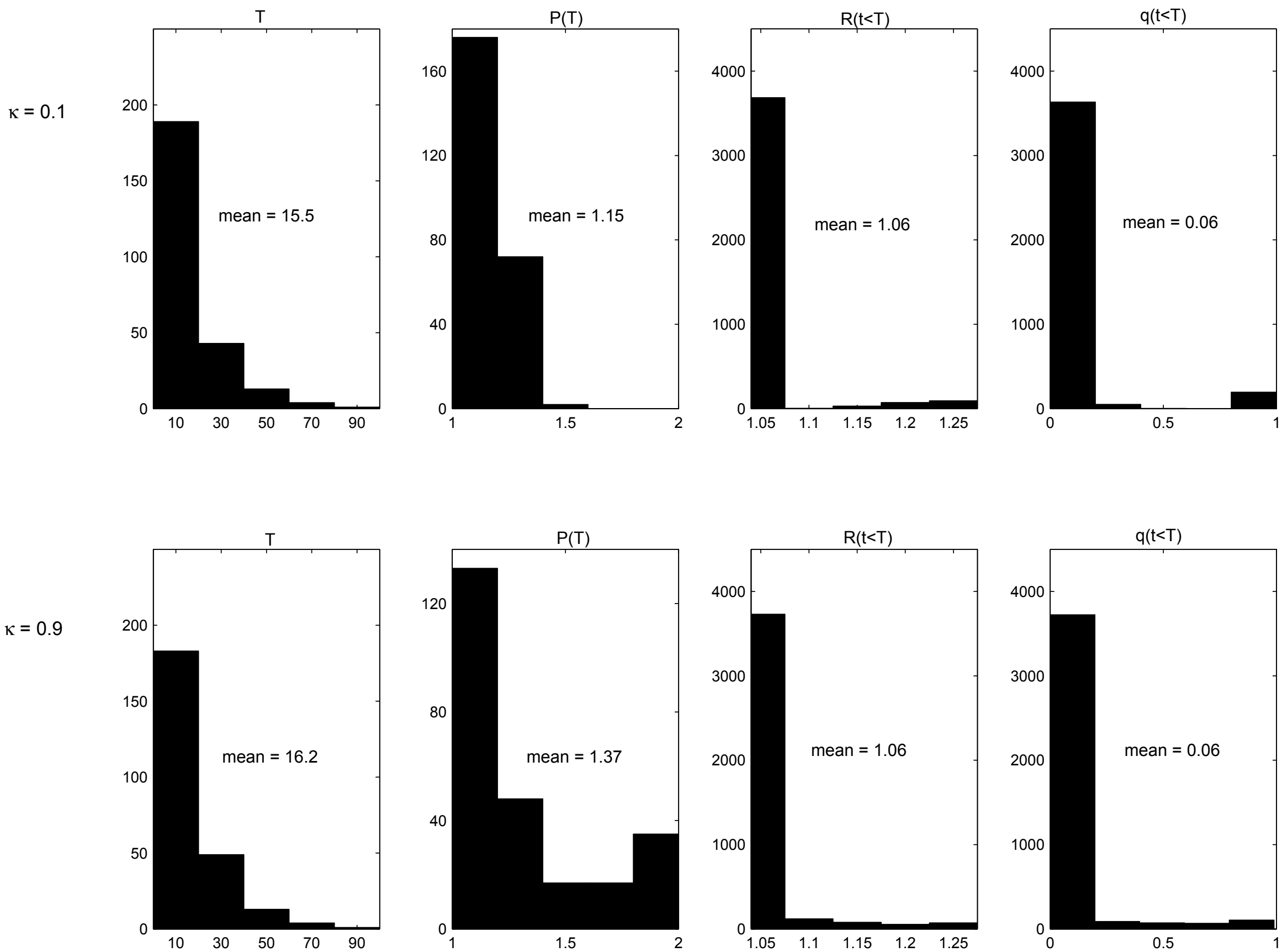

Note: The parameter values are the same as in the benchmark economy except as indicated to the left of each row. Histograms are based on 250 simulations of the model. T denotes the period in which the regime switch occurs. 
Figure 6: Examples of time series simulated from the model
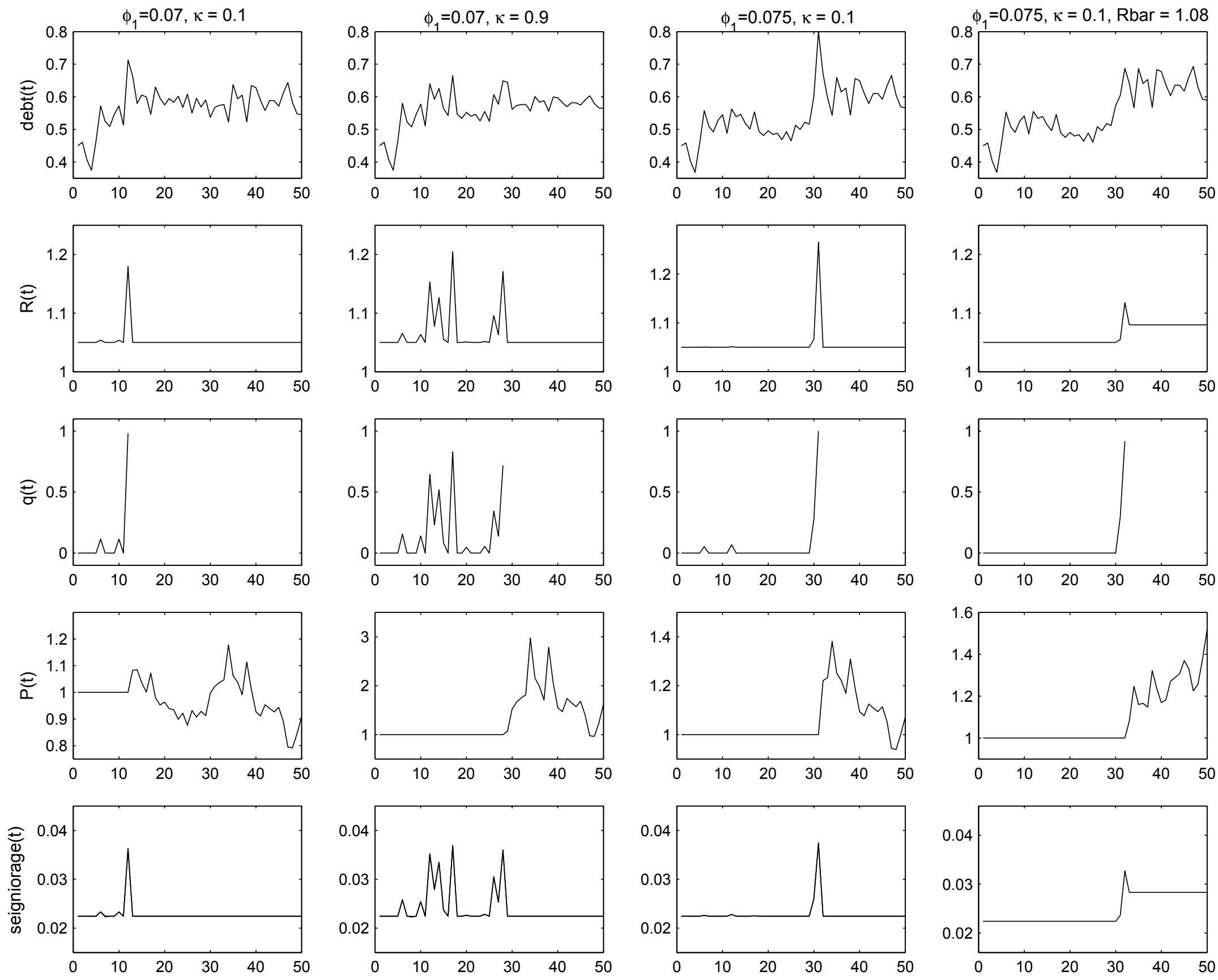

Note: Each simulation uses the same shocks and different parameter values.

The parameter values are the same as in the benchmark economy except as indicated above each column. 


\section{SFB 649 Discussion Paper Series 2006}

For a complete list of Discussion Papers published by the SFB 649, please visit http://sfb649.wiwi.hu-berlin.de.

001 "Calibration Risk for Exotic Options" by Kai Detlefsen and Wolfgang K. Härdle, January 2006.

002 "Calibration Design of Implied Volatility Surfaces" by Kai Detlefsen and Wolfgang K. Härdle, January 2006.

003 "On the Appropriateness of Inappropriate VaR Models" by Wolfgang Härdle, Zdeněk Hlávka and Gerhard Stahl, January 2006.

004 "Regional Labor Markets, Network Externalities and Migration: The Case of German Reunification" by Harald Uhlig, January/February 2006.

005 "British Interest Rate Convergence between the US and Europe: A Recursive Cointegration Analysis" by Enzo Weber, January 2006.

006 "A Combined Approach for Segment-Specific Analysis of Market Basket Data" by Yasemin Boztuğ and Thomas Reutterer, January 2006.

007 "Robust utility maximization in a stochastic factor model" by Daniel Hernández-Hernández and Alexander Schied, January 2006.

008 "Economic Growth of Agglomerations and Geographic Concentration of Industries - Evidence for Germany" by Kurt Geppert, Martin Gornig and Axel Werwatz, January 2006.

009 "Institutions, Bargaining Power and Labor Shares" by Benjamin Bental and Dominique Demougin, January 2006.

010 "Common Functional Principal Components" by Michal Benko, Wolfgang Härdle and Alois Kneip, Jauary 2006.

011 "VAR Modeling for Dynamic Semiparametric Factors of Volatility Strings" by Ralf Brüggemann, Wolfgang Härdle, Julius Mungo and Carsten Trenkler, February 2006.

012 "Bootstrapping Systems Cointegration Tests with a Prior Adjustment for Deterministic Terms" by Carsten Trenkler, February 2006.

013 "Penalties and Optimality in Financial Contracts: Taking Stock" by Michel A. Robe, Eva-Maria Steiger and Pierre-Armand Michel, February 2006.

014 "Core Labour Standards and FDI: Friends or Foes? The Case of Child Labour" by Sebastian Braun, February 2006.

015 "Graphical Data Representation in Bankruptcy Analysis" by Wolfgang Härdle, Rouslan Moro and Dorothea Schäfer, February 2006.

016 "Fiscal Policy Effects in the European Union" by Andreas Thams, February 2006.

017 "Estimation with the Nested Logit Model: Specifications and Software Particularities" by Nadja Silberhorn, Yasemin Boztuğ and Lutz Hildebrandt, March 2006.

018 "The Bologna Process: How student mobility affects multi-cultural skills and educational quality" by Lydia Mechtenberg and Roland Strausz, March 2006.

019 "Cheap Talk in the Classroom" by Lydia Mechtenberg, March 2006.

020 "Time Dependent Relative Risk Aversion" by Enzo Giacomini, Michael Handel and Wolfgang Härdle, March 2006.

021 "Finite Sample Properties of Impulse Response Intervals in SVECMs with Long-Run Identifying Restrictions" by Ralf Brüggemann, March 2006.

022 "Barrier Option Hedging under Constraints: A Viscosity Approach" by Imen Bentahar and Bruno Bouchard, March 2006.

\section{SFB 649, Spandauer Straße 1, D-10178 Berlin} http:/ / sfb649.wiwi.hu-berlin.de

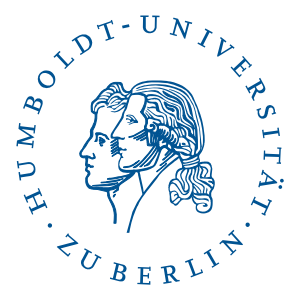


023 "How Far Are We From The Slippery Slope? The Laffer Curve Revisited" by Mathias Trabandt and Harald Uhlig, April 2006.

024 "e-Learning Statistics - A Selective Review" by Wolfgang Härdle, Sigbert Klinke and Uwe Ziegenhagen, April 2006.

025 "Macroeconomic Regime Switches and Speculative Attacks" by Bartosz Maćkowiak, April 2006. 